\title{
Stars or Starlets of Sustainable Development
}

\author{
Janusz Grabara ${ }^{1}$ * \\ ${ }^{1}$ Częstochowa University of Technology. Faculty of Management. Department of Engineering \\ Management Dąbrowskiego 69. 42-201 Czestochowa Poland \\ $\underline{\text { janusz@grabara.eu) }}$
}

\begin{abstract}
Sustainable development can be understood in different ways. It should be noted that for sustainable development are assigned important factors referred to as stars and less important referred to as starlets. It is important to remember that factors such as energy, population, food, and economy manage correlations between them. In this area a very important element is the information dissemination about stars that means the dominant raw materials used to produce energy and starlets considered as renewable energy sources, those importance in global scale is relatively small but significant in terms of sustainability
\end{abstract}

Keywords: sustainable development, energy, population, economy

\section{Introduction}

Since its introduction, sustainability has been defined in dozens of different ways in different contexts and disciplines $[1,2,3]$.The first internationally recognised definition of sustainability is that of World Council of Environment and Development [4]. That defines sustainability as 'the development that meets the needs of the present generation without compromising the ability of the future generations to meet their own needs'. This means today's actions have corresponding effects to future generations [5]. Considering "sustainability definitions" it can be found that it has many definitions because it depends on economic, environmental and social components and each may have its own definitions [6]. Some of the sustainability development understandings can be beyond the science getting even philosophical meaning [7].

At the moment the concept of Sustainable Development has become the key to positive consideration of any project $[8,9,10]$. As long as the definition of sustainable development appears in the project description, the chances of obtaining funding for the project are increasing several times. The reality is that it is not known what this sustainable is. Michael D. Lemonick is a senior writer at Climate Central, a nonprofit climate change think tank in Princeton, N.J. was orig- 
inally published this article with the title "Top 10 Myths About Sustainability" [11]. The article points to certain shortcuts that have no reference to the reality:

- Nobody knows what sustainability really means,

- Sustainability is all about the environment.

- "Sustainable" is a synonym for "green." [12]

- It's all about recycling.

- Sustainability is too expensive.

- Sustainability means lowering our standard of living.

- Consumer choices and grassroots activism, not government intervention, offer the fastest, most efficient routes to sustainability,

- New technology is always the answer.

- Sustainability is ultimately a population problem.

- Once you understand the concept, living sustainably is a breeze to figure out. As you can see, everyone understands the concept of balance in a comfortable way.

It should be assumed that it would be more appropriate to divide the stars and starlets in the spectacle of sustainable development. And here you have to start with mega stars in metaphorical and in fact what is sun. Publication aim is an introduction to the discussion on effectiveness and economic efficiency of sustainable development.

\section{Sun mega star of sustainable development}

The whole history of humanity as well as planet Earth is the result of the sun's influence. Millions of years of sunshine have allowed for such a different shape of the Earth and the development of our civilization. Keep in mind that this is the sun that is the only provider of energy, which in the scale of civilization is inexhaustible and most importantly free. It is thanks to this energy that all processes on Earth take place. In addition, it is an energy that does not generate hazardous waste, ash dumps or other by-products. That is why remain a mega star of development and development that, in many definitions, is balanced. The problem is only skilful use of this energy. Skilful use in the sense of achieving such technological solutions that will make the use of solar energy economically viable [13]. So far, solar installations like winds do not actually pay for the costs of building and operating them, and they only exist in projects funded by governments and organizations. Most often, this refers to the production of electricity, which is constantly a problem when considering its storage on an industrial scale. It is much easier to store natural fuels such as coal, crude oil, natural gas. At present in this area the star is coal. 


\section{Coal still the current star of electricity production}

Identifying the star for carbon in the area of sustainable development is in the pejorative sense. Nevertheless, according to statistics, it is coal that most electricity is produced from. Data of energy produktion show energy produced in 2017 since 1 st January until 11-02-2017

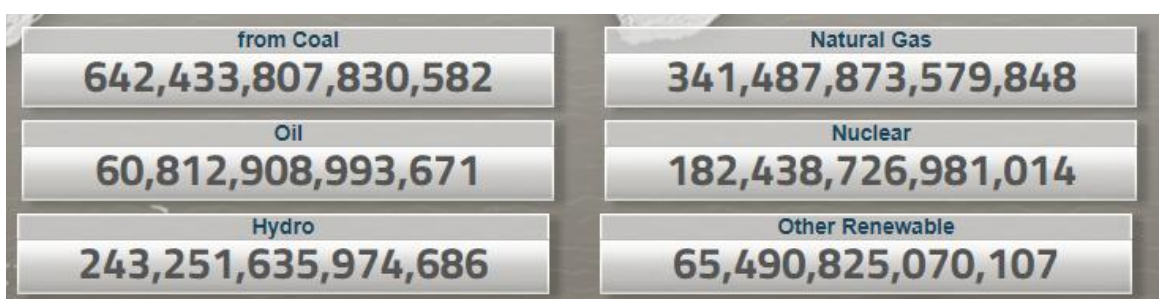

Fig 1 Electricity production in 2017 (in kWh) until 11-02-2017, source [14]

Renewable energy (excluding hydropower) accounts for only $4.2 \%$ of electricity production worldwide Electricity generation in hydroelectric power plants, the oldest renewable energy sources, generates $15.6 \%$ of total electricity. Nuclear power plants produce almost $12 \%$. In France about $80 \%$ of power comes from nuclear power plants. Worldwide, $41 \%$ of the electricity comes from coal (43\% in the US). China produces $4715.7 \mathrm{TWh} /$ year, which accounts for $79 \%$ of all electricity in poorly regulated power plants. These statistics come from World Bank reports [15].

The value of electricity generated from renewable sources is only $4.2 \%$ of global production. So we can qualify as a small rising starlet in sustainable development. However, the question remains whether the growth of this star will be so large in the coming years to meet the increased demand for climate warming and the introduction of new energy efficiency solutions such as electric cars and other such solutions.

"The Guardian," published data compiled by the British operator National Grid, a significant increase in the number of electric cars in the UK could result in peak power demand by 2030 surpassing the capabilities of its power system, supplemented even by the Hinkley [16]. By 2030, the number of passenger cars and vans in the UK is expected to reach 9 millions. At present there are 90 thousand of them. Loading too many car batteries would have the effect of reversing the declining trend in demand for energy in recent years. This is related to activities undertaken to increase energy efficiency. If electric vehicles will not be loaded in such a way as to avoid peaks and falls in power demand, for example during the hours between five and six in the afternoon when people return to homes, then peak demand for power can be up by $8 \mathrm{GW}$.

Moving the charging time for a period when the energy demand is lower could reduce the peak demand for power to $3.5 \mathrm{GW}$. It's less than in the previous scenario, but it's still about the same size as the Hinkley Point C (3.2 GW). 
In this simple example, it can be said that making changes without prospecting in this case increased demand for electricity can lead to severe system failures. So global electricity generation will continue to rely on coal for many years to come. Therefore, we can not now talk about sustainability in electricity production, as fossil sources such as the star Coal and about half the stars of the Oil and Gas are dominant in this area. And renewable energy sources are tiny rising starlet with a small share of less than $5 \%$ in electricity generation worldwide.

\section{Population the current star foodproduction and life level}

Considering important factors, such as stars and stars of sustainable development, the demographic factor can not be ignored. Demography is definitely a star, but the star is ambiguous, it is difficult to pinpoint what has a positive impact on sustainable development or negative. On the other hand, because of its importance, it is certainly a star.

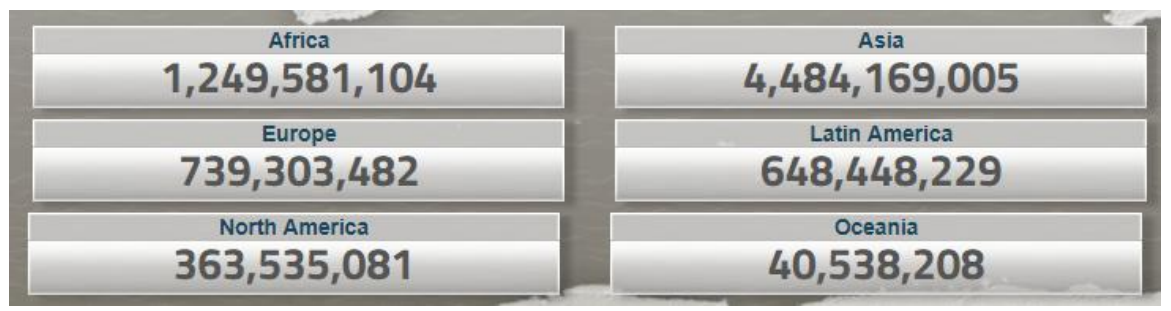

Fig 2 World population at 11-02-2017, source [14]

The world population data from the UN Population Division. The UNPD demographers (population statisticians) estimate that the world is growing by $1.18 \%$ (over 80 million people) per year. They project that this trend will gradually stabilize and in many regions they predict population decline. Even China will likely peak in 40 years. Africa, however, is not expected to slow it's growth. By the end of the century $40 \%$ of the world's population will be in Africa. UNITED NATIONS DESA / POPULATION DIVISION World Population Prospects 2017

Over 7.5 billion people live in the world right now. The United Nations (UN) long-term forecasts for 2100 are to have 11 billion people on Earth. Half of the world's population lives on only 1 percent of the land area. Half of the population resides in Asia, population dispersion is steadily decreasing [17]. In Tokyo, the capital of Japan, with suburbs there are more than 40 million people, which is more than in Poland. Most of us are in temperate and subtropical areas. The farther to the poles, the smaller the population, and all indications are that it will stay that way in the future, unless there are some drastic climate changes waiting for us. According to the UNDPD statistics, by 2100, the population of Africa will definitely increase and the rest of the continent will have a population similar to the 
present. Although the earth is still not overcrowded in terms of space occupied by us, it is due to problems with food production, overfishing of fish, soil and air contamination, and the use of mineral resources. Therefore, demographic policies related to population growth and food insecurity for this population should be conducted on a global scale, which is unacceptable in today's circumstances and is not a factor in star status. Stars that are definitely far from sustainable development.

\section{Conclusion Economy Star}

The deliberations presented in this paper are intended to stimulate discussion and possibly coordinated action in the area of approaching sustainable development. Since the current activities are implemented on a micro scale and locally. There is no clear and common policy supporting the pursuit of sustainable development. One of the reasons is a star called an economy. In principle, all countries in the world are indebted so a large proportion of their revenues are devoted to debt servicing and the implementation of current affairs relevant to the state or to meet the needs of the population. In this case, the global action or near-indefinite execution date goes to a further plan. The best example of such action is the withdrawal of the US from the Paris Climate Change Agreement.

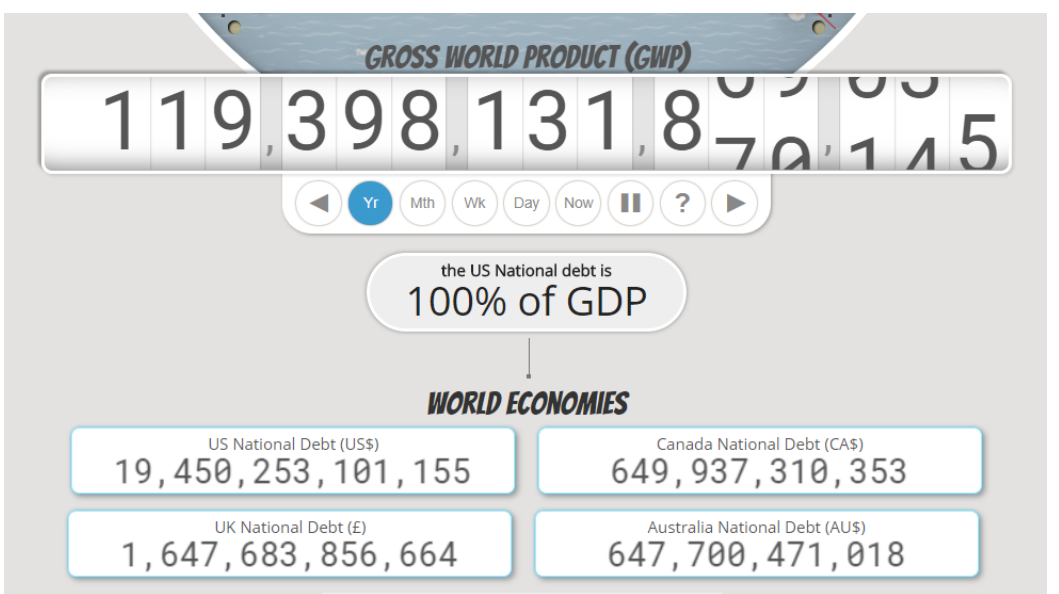

Fig 3 Selected countrys debt situation. source [14]

As shown in Figure 3, budget deficits of the largest countries are close to GDP. Such a state of affairs means that decisive and effective actions in pursuit of regional development do not have global support. The Economy Star is almost as strong as the SUN star, with the only difference being that the Sun has no influence and that is a positive aspect, and the economy is influenced by politicians and also most often affected by it. 


\section{References}

[1] Filho, L. W., 2000, Dealing with Misconception on the Concept of Sustainability, International Journal of Sustainability in Higher Education, 1(1): 1121

[2] Shrivastava, P., 2010, Pedagogy of Passion for Sustainability, Academy of Management Learning and Education, 9(3): 443-455

[3] Rajnoha R., Lesníková P., 2016, Strategic Performance Management System and Corporate Sustainability Concept - Specific Parametres in Slovak Enterprises, Journal of Competitiveness, 8(3), 107-124

[4] Du Pisani, A. J., 2006, Sustainable Development-Historical Root of the Concept, Environmental Sciences, 3(2): 83-96

[5] Bell, S., and Morse, S., 1999, Sustainability Indicators Measuring the Immeasurable, London, Earth Scan

[6] Grabara, J.K., 2017, The another point of view on sustainable management, Quality - Access to Success, 18, 344-349.

[7] Grabara, J., Vlăduţescu, Ş., Kot, S., 2016, Philosophical background of reverse logistics, Analele Universitatii din Craiova, Seria Filozofie, 38(2), pp. 158-167.

[8] Manole, A.L., Grabara, I., 2016, Methodologies and visualization tools of effective project management, Polish Journal of Management Studies, 14(2), 137-149.

[9] Dobrovolskienè, N., Tvaronavičienè, M., Tamošiūnienè, R., 2017, Tackling projects on sustainability: a Lithuanian case study, Entrepreneurship and Sustainability Issues, 4(4), 477-488. https://doi.org/10.9770/jesi.2017.4.4(6)

[10] Stjepanović, S., Tomić, D., Škare, M., 2017, A new approach to measuring green GDP: a cross-country analysis, Entrepreneurship and Sustainability Issues, 4(4), 574-590. https://doi.org/10.9770/jesi.2017.4.4(13)

[11] https://www.scientificamerican.com/article/top-10-myths-aboutsustainability/

[12] Askadilla, W.L., Krisjanti, M.N., 2017, Understanding indonesian green consumer behavior on cosmetic products: Theory of planned behavior model, Polish Journal of Management Studies, 15(2), 7-15.

[13] Mikita, M., Kolcun, M., Špes, M., Vojtek, M., Ivančák, M., 2017, Impact of electrical power load time management at sizing and cost of hybrid renewable power system Polish Journal of Management Studies, 15(1), 154162.

[14] http://www.poodwaddle.com/worldclock/env4/

[15] wbk/wbpubs/24985.html /9781464808524.pdf

[16] http://www2.nationalgrid.com/UK/Our-company/Electricity/Balancing-thenetwork/ Point power plant.

[17] http://www.twojapogoda.pl/news/115932,ile-jam-homes-moon-moontourism 